\title{
Ketotic (Idiopathic Glucagon Unresponsive) Hypoglycaemia: Diazoxide Effects ${ }^{\star}$
}

\author{
ARLAN L. ROSENBLOOM \\ From the Division of Genetics, Endocrinology, and Metabolism, Department of Pediatrics, University of Florida College \\ of Medicine, Gainesville, Florida, U.S.A.
}

\begin{abstract}
Rosenbloom, A. (1972). Archives of Disease in Childhood, 47, 544. Ketotic (idiopathic glucagon unresponsive) hypoglycaemia: diazoxide effects. Glucagon unresponsiveness in the fasting state characterizes a variety of hypoglycaemia with infrequent episodes usually occurring in the early morning with good health between attacks. Vomiting commonly accompanies the episodes. This variety of idiopathic hypoglycaemia has been called 'ketotic hypoglycaemia', but ketonuria may be an inconsistent finding. 13 patients were compared to 8 contrast subjects with other varieties of hypoglycaemia and to 7 children without hypoglycaemia to confirm the abnormality of response to glucagon in the fasting state. 9 children were studied before and after treatment with diazoxide, $15 \mathrm{mg} / \mathrm{kg}$ per day for 3 days. 6 subjects experienced restoration of fasting glucagon response with diazoxide. The difference between responding and nonresponding subjects could either be due to variability in expression of the same metabolic defect or represent different defects in fasting energy metabolism.
\end{abstract}

A form of hypoglycaemia characterized by infrequent episodes occurring after a period of food deprivation or with illness and associated with acetonuria and vomiting was defined by Colle and Ulstrom (1964) and Sauls and Ulstrom (1967). They called this entity 'ketotic hypoglycaemia'. These children are well between attacks, do not have delayed hypoglycaemia with glucose loading, and do not have hepatomegaly. When fed normally and fasted for 12 hours, they responded to glucagon or epinephrine injection with a normal rise in blood glucose. With caloric and carbohydrate deprivation, acetonuria and hypoglycaemia develop after 18 hours and the children no longer respond to glucagon.

A number of mechanisms have been proposed for the hypoglycaemic episodes and the lack of glucagon responsiveness. Colle and Ulstrom (1964) suggested that the appearance of hypoglycaemia represented a failure to adapt to a fasting economy.

Received 10 January 1972.

*This work was supported by the Developmental Physiology Training Grant, NIH T1-HD0054, NIH Research Grant 2M01RR-00082, General Research Support Grant 623, NIH Training Grant 1 TO1-AMO-5680-01 DM, and aided by a grant from the National Foundation-March of Dimes.

Read at the 1970 Annual Meeting of the Southern Society for Pediatric Research, New Orleans, 20-21 November 1970.
Adaptation normally involves heightened lipolysis with ketone formation and utilization (Van Itallie and Bergen, 1961), decreased glucose utilization, and gluconeogenesis with continuous replenishing of hepatic glycogen stores (Cahill et al., 1966; Nitzan et al., 1968).

The nondiuretic benzothiadiazine diazoxide, has hyperglycaemic effects by virtue of its ability to suppress insulin release and by its endogenous sympathetic stimulation (Loubatières, Mariani, and Alric, 1968; Graber, Porte, and Williams, 1966). Heightened glucose disposal (Grunt et al., 1970) and glycogen depletion (Sauls, 1966) have been described in the ketotic variety of hypoglycaemia, and basal insulin deficiency with enhanced fasting glycogenolysis has been proposed as a mechanism (Kogut, Blaskovics, and Donnell, 1969). It was of interest to explore the influence on this condition of a drug with a variety of effects on glucose metabolism. Increased glycogenolysis might accentuate the problem, but increased lipolysis and ketone formation with decreased peripheral glucose utilization are effects of potential benefit.

The present study is a clinical analysis of 13 children with ketotic hypoglycaemia and a description of the responses to diazoxide administration. 


\section{Materials and Methods}

Thirteen children with hypoglycaemia associated with glucagon unresponsiveness in the fasting state were studied. They were admitted to our unit for the studies reported here after symptomatic episodes associated with blood glucose concentration less than $40 \mathrm{mg} / 100 \mathrm{ml}$ had been observed and fasting glucagon unresponsiveness had been established. 8 children with glucagon responsive hypoglycaemia ( 7 idiopathic, 1 growth hormone deficient) and 7 normal children aged 4-14 years comprised comparison groups.

No testing was done during illness or convalescence. Oral glucose tolerance was tested after an overnight fast of 9 to 12 hours, using a test load of $1.75 \mathrm{~g}$ of a cola-flavoured carbohydrate solution per $\mathrm{kg}$ body weight up to a maximum of $75 \mathrm{~g}$. Plasma glucose was analysed by the ferricyanide method on the Autoanalyzer (Technicon Autoanalyzer Methodology N-2A). Radioimmunoassay of plasma insulin was performed in duplicate by the method of Yalow and Berson (1960).

After withdrawal of the 4-hour postglucose loading specimen, an injection of $1 \mathrm{mg}$ glucagon was given and specimens obtained at $15,30,45$, and 60 minutes thereafter. This was considered the fed glucagon tolerance test. The patient was then given a normal diet until 2 to 4 p.m. the following day when a 24-hour fast began after a snack. Ingestion of the unpalatable ketogenic diet has been found to be poor. Fasting with the provision of adequate fluid has been substituted as a more reliable and standard deprivation (Drash, 1971). The fasting period was ended when the patient showed moderate to marked ketonuria or had symptoms of hypoglycaemia, or arbitrarily at the end of 24 hours. One subject was fasted for 30 hours before we set the 24-hour limit. At the end of the fast a blood specimen was obtained, glucagon was given intravenously in a dose of $1 \mathrm{mg}$, and repeat specimens obtained 15, 30, 45 , and 60 minutes thereafter.

In 9 of the glucagon unresponsive (ketotic) subjects these studies were repeated after 3 to 4 days of treatment with diazoxide, $15 \mathrm{mg} / \mathrm{kg}$ body weight per day divided into 3 or 4 oral doses.

\section{Results}

Clinical data on the 13 patients with glucagon unresponsiveness and the 8 patients with glucagon responsive hypoglycaemia are presented in the Table. Prematurity, low birthweight for gestational age, and perinatal stress were more common in the glucagon unresponsive group (Grunt et al., 1970; Habbick, McNeish, and Stephenson, 1971). Though most of the children with glucagon unresponsiveness developed hypoglycaemia after 1 year of age, one patient had her first episode at 2 days of age, and another at 7 months of age. 7 of the 13 children had a height age to chronological age ratio of less than $0 \cdot 8$, but only 2 of them were less than $89 \%$ of ideal weight for their height.
2 of the children had developmental quotients below 60,2 were in the borderline range of 75 to 85 , and the rest were normal. There was no relation between low birthweight or severity of seizures and retardation. None of the children with glucagon unresponsiveness had hepatomegaly or other significant physical abnormalities or congenital malformations.

The episodes of hypoglycaemia varied from weakness and fatigue to unconsciousness and/or grand mal seizures. In only 2 of the 13 patients did the spells ever occur at any time other than before breakfast. In 12 of the 13 patients vomiting was associated with the hypoglycaemic episodes, and this was not found to be a feature in any of the contrast group. Hypoglycaemic spells were quite intermittent, varying from monthly to yearly. There was no hypoglycaemia during the oral glucose tolerance test in any of the patients, but chemical hypoglycaemia (plasma glucose concentration less than $45 \mathrm{mg} / 100 \mathrm{ml}$ ) occurred during the testing in 7 of the 8 contrast subjects. Follow-up studies have been carried out at yearly intervals on 6 of the patients during the $3 \frac{1}{2}$ years of this investigation. Two patients, Cases 1 and 2, $1 \frac{1}{2}$ and 1 year, respectively, after initial studies no longer showed hypoglycaemia and responded normally to glucagon after a 24-hour fast. One child (Case 12) developed clinical and chemical glucagon unresponsive hypoglycaemia on follow-up testing even though he had not had a spell for $1 \frac{1}{2}$ years.

The period of standard fasting varied from 18 to 30 hours. Moderate to marked ketonuria was the reason for stopping the fast in only 3 instances and in 2 of these instances sympathetic symptoms were present. 5 other patients had trace or little acetonuria, 3 with adrenergic symptoms. Testing of 5 patients ended with no acetonuria; 4 had significant symptomatology. At the end of the fast, none of the patients had a significant response to glucagon injection. Patients in the contrast and control groups had marked responses (Fig. 1). In the fed state the glucagon responsiveness of the patients was normal (Fig. 1). Compared to the other groups the patients with glucagon unresponsive hypoglycaemia had normal insulin response during the fed glucagon tolerance test (Fig. 1). When fasting they did not show a rise in plasma insulin levels after glucagon and this was consistent with the failure of glucose response.

The effect of diazoxide treatment on glucagon responsiveness in the fasting state is shown in Fig. 2. 6 of the children experienced a hyperglycaemic response to glucagon in the fasting state while on diazoxide: 3 of the patients did not. 
Clinical Data on 13 Children with Ketotic (Idiopathic Glucagon Unresponsi

\begin{tabular}{|c|c|c|c|c|c|c|c|c|c|c|c|}
\hline \multirow{2}{*}{$\begin{array}{l}\text { Case } \\
\text { No. }\end{array}$} & \multirow{2}{*}{ Sex } & \multirow{2}{*}{$\begin{array}{l}\text { Age } \\
(\mathrm{yr})\end{array}$} & \multirow{2}{*}{$\begin{array}{c}\text { Height } \\
\text { Age/ } \\
\text { Chronological } \\
\text { Age }\end{array}$} & \multirow{2}{*}{$\begin{array}{l}\text { Weight } \% \\
\text { of Ideal } \\
\text { for } \\
\text { Height }\end{array}$} & \multirow{2}{*}{$\begin{array}{l}\text { Birthweight } \\
\text { (g) }\end{array}$} & \multirow{2}{*}{$\begin{array}{c}\text { Developmental } \\
\text { Quotient }\end{array}$} & \multirow{2}{*}{$\begin{array}{c}\text { Age } \\
\text { Onset (yr) }\end{array}$} & \multirow{2}{*}{ Vomiting } & \multicolumn{3}{|c|}{ Hypoglycaemic Episod } \\
\hline & & & & & & & & & $\begin{array}{l}\text { Time of } \\
\text { Day }\end{array}$ & Severity & $\begin{array}{c}\text { Frequenc } \\
\text { ญ } \\
\end{array}$ \\
\hline $\begin{array}{r}1 \\
2 \\
3 \\
4 \\
5 \\
6 \\
7 \\
8 \\
9 \\
10 \\
11 \\
12 \\
13\end{array}$ & $\begin{array}{l}F \\
F \\
M \\
M \\
F \\
F \\
M \\
M \\
M \\
M \\
M \\
M \\
F\end{array}$ & $\begin{array}{ll}1 & 3 / 12 \\
2 & 5 / 12 \\
4 & 10 / 12 \\
5 & 2 / 12 \\
5 & 7 / 12 \\
6 & 10 / 12 \\
7 & 9 / 12 \\
5 & 9 / 12 \\
5 & 9 / 12 \\
9 & 5 / 12 \\
2 & 9 / 12 \\
7 & \\
3 & 6 / 12\end{array}$ & $\begin{array}{l}0.27 \\
1 \cdot 10 \\
0.73 \\
0.69 \\
0.90 \\
0.77 \\
1 \cdot 07 \\
0.61 \\
0.59 \\
0.96 \\
0.80 \\
0.90 \\
1.05\end{array}$ & $\begin{array}{r}100 \\
92 \\
100 \\
89 \\
85 \\
89 \\
105 \\
90 \\
83 \\
100 \\
105 \\
88 \\
90\end{array}$ & $\begin{array}{l}1020 \\
3270 \\
1110 \\
3600 \\
1570 \\
1450 \\
4560 \\
1020 \\
1170 \\
2310 \\
3550 \\
2180 \\
4100\end{array}$ & $\begin{array}{c}70 \\
100 \\
77 \\
105 \\
\text { Normal } \\
85 \\
103 \\
\text { Normal } \\
107 \\
56 \\
\text { Normal } \\
91 \\
\text { Normal }\end{array}$ & $\begin{array}{ll}2 & \text { days } \\
1 & 3 / 12 \\
2 & 6 / 12 \\
2 & 6 / 12 \\
4 & 1 / 12 \\
4 & \\
& 7 / 12 \\
3 & 9 / 12 \\
3 & 8 / 12 \\
1 & 6 / 12 \\
2 & 3 / 12 \\
2 & 6 / 12 \\
3 & \end{array}$ & $\begin{array}{l}+ \\
0 \\
+ \\
+ \\
+ \\
+ \\
+ \\
+ \\
+ \\
0 \\
+ \\
+ \\
+\end{array}$ & $\begin{array}{l}\text { a.m. } \\
\text { a.m. } \\
\text { a.m. } \\
\text { a.m. } \\
\text { a.m. } \\
\text { a.m. } \\
\text { a.m. } \\
\text { a.m. } \\
\text { a.m. } \\
\text { Mostly a.m. } \\
\text { a.m. } \\
\text { a.m. } \\
\text { a.m. }\end{array}$ & $\begin{array}{l}4 \\
2-3 \\
1-4 \\
1-3 \\
3 \cdot 4 \\
3-4 \\
3 \\
2-4 \\
2-4 \\
4 \\
2 \\
1-4 \\
1-3\end{array}$ & 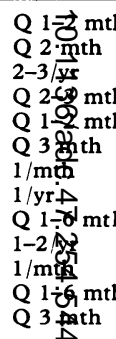 \\
\hline $\begin{array}{l}14 \\
15 \\
16\end{array}$ & $\begin{array}{l}M \\
M \\
F\end{array}$ & $\begin{array}{r}19 / 12 \\
28 / 12 \\
4 / 12\end{array}$ & $\begin{array}{l}0.62 \\
0.53 \\
1 \cdot 00\end{array}$ & $\begin{array}{r}125 \\
95 \\
80\end{array}$ & $\begin{array}{l}2880 \\
1080 \\
3690\end{array}$ & $\begin{array}{l}\text { Normal } \\
\text { Normal } \\
\text { Normal }\end{array}$ & $\begin{array}{l}\text { Birth } \\
27 / 12 \\
2 / 12\end{array}$ & $\begin{array}{l}0 \\
0 \\
0\end{array}$ & $\begin{array}{l}\text { Varied } \\
\text { a.m. } \\
\text { a.m. }\end{array}$ & $\begin{array}{l}4 \\
4 \\
3\end{array}$ & 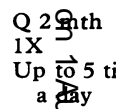 \\
\hline $\begin{array}{l}17 \\
18 \\
19 \\
20\end{array}$ & $\begin{array}{l}\mathrm{F} \\
\mathrm{M} \\
\mathrm{F} \\
\mathrm{M}\end{array}$ & $\begin{array}{ll}5 & \\
1 & 2 / 12 \\
1 & \\
1 & 5 / 12\end{array}$ & $\begin{array}{l}0 \cdot 80 \\
1 \cdot 04 \\
0 \cdot 90 \\
1 \cdot 10\end{array}$ & $\begin{array}{l}112 \\
104 \\
100 \\
100\end{array}$ & $\begin{array}{l}4200 \\
3850 \\
2650 \\
3374\end{array}$ & $\begin{array}{c}67 \\
\text { Normal } \\
20-40 \\
70\end{array}$ & $\begin{array}{c}1 \\
1 \\
5 / 12 \\
5 / 12 \\
5 / 12\end{array}$ & $\begin{array}{l}0 \\
0 \\
0 \\
0\end{array}$ & $\begin{array}{l}\text { Varied } \\
\text { Varied } \\
\text { Varied } \\
\text { Varied }\end{array}$ & $\begin{array}{l}1-4 \\
1-4 \\
2-4 \\
1-4\end{array}$ & $\begin{array}{l}1-2 \sqrt{\sigma} k \\
\text { Dai } \\
1 / \mathrm{me} \\
\text { Weetty to } \\
\text { dally }\end{array}$ \\
\hline 21 & $\mathbf{M}$ & $49 / 12$ & 0.98 & 100 & 3500 & Normal & $43 / 12$ & 0 & a.m. & $1-2$ & Q $2 \mathrm{P}^{3} \mathrm{mt}$ \\
\hline
\end{tabular}

Note: ${ }^{\star}$ Severity and symptoms of hypoglycaemia: 1 = weakness, fatigue; $2=$ pallor, sweating, tachycardia; $3=$ eye rolling, mental changętren tHighest value.

$\ddagger$ Seizure with glucose of $29 \mathrm{mg} / 100 \mathrm{ml}$ one hour after glucagon.

Diazoxide produced a diabetic glucose tolerance curve in all but one subject. There was no significant difference in diabetogenic effect of the drug in the responding and nonresponding patients. Mean insulin responses did not vary significantly with treatment or between responders and nonresponders (Fig. 3).

\section{Discussion}

'Ketotic hypoglycaemia' may not be the best term for the syndrome of intermittent hypoglycaemia, usually associated with vomiting, occurring in the early morning, and distinguished by glucagon unresponsiveness. Ketonuria may not be a necessary accompaniment of this syndrome. Since ketonuria also occurs in other forms of hypoglycaemia which are glucagon responsive as well as in normal children who are fasted (Colle and Ulstrom, 1964; Sauls, 1966), a more specific designation may be useful. Unlike children with other varieties of hypoglycaemia, these patients have normal blood glucose levels between episodes and after overnight fasting. In addition, they do not show hypoglycaemia during the oral glucose tolerance test. The distinguishing feature of this variety of idiopathic hypoglycaemia is not ketonuria but glucagon unresponsiveness in the fasting state.

Normal children who become ill with dehydration, vomiting, and ketosis do not have hypoglycaemia (Darrow and Cary, 1935), and they respond to glucagon with a rise in blood glucose concentration and a fall in free fatty acid levels (Nitzan and Kowadlo-Silbergeld, 1966). In other varieties of idiopathic or endocrinopathic hypoglycaemia, the fall in blood sugar tends to occur earlier during the fast and glucagon responsiveness is invariably present.

The pathogenic mechanism for this variety of hypoglycaemia remains elusive. Kogut et al. N (1969) found diminished plasma insulin responses to tolbutamide and l-leucine and suggested that failure of fasting insulin to maintain liver glycogen $\mathrm{\omega}$ was an important mechanism for the development of hypoglycaemia and lack of glucagon response. However, Grunt et al. (1970) have found normal insulin responses to 1-leucine and fasting insulin levels are normal (Sauls, 1966; Senior and Loridan, 1969). Our finding of normal insulin responses to glucose and glucagon and normal levels of plasma 
poglycaemia and 8 Contrast Children with Glucagon Responsive Hypoglycaemia

\begin{tabular}{|c|c|c|c|c|c|c|}
\hline \multirow{3}{*}{$\begin{array}{l}\text { ypoglycaemia } \\
\text { During } \\
\text { OGTT }\end{array}$} & \multicolumn{5}{|c|}{ Fast } & \multirow{3}{*}{ Comment } \\
\hline & \multirow{2}{*}{$\begin{array}{l}\text { Duration } \\
\text { (hr) }\end{array}$} & \multirow{2}{*}{ Ketonuria } & \multirow{2}{*}{ Symptoms* } & \multicolumn{2}{|c|}{ Plasma Glucose } & \\
\hline & & & & $\begin{array}{c}\text { End of } \\
\text { Fast }\end{array}$ & $\begin{array}{c}\text { After } \\
\text { Glucagon }\end{array}$ & \\
\hline $\begin{array}{l}\text { No } \\
\text { No } \\
\text { No } \\
\text { No } \\
\text { No } \\
\text { No } \\
\text { No } \\
\text { No } \\
\text { No } \\
\text { No } \\
\text { No } \\
\text { No } \\
\text { No }\end{array}$ & $\begin{array}{l}18 \\
23 \\
20 \\
19 \\
24 \\
30 \\
22 \\
24 \\
20 \\
23 \\
24 \\
18 \\
24\end{array}$ & $\begin{array}{c}++ \\
+++ \\
++ \\
\pm \\
0 \\
+ \\
0 \\
0 \\
+ \\
+ \\
+ \\
0 \\
0\end{array}$ & $\begin{array}{l}2 \\
2 \\
0 \\
2 \\
0 \\
2 \\
2 \\
3 \\
2 \\
0 \\
1 \\
3 \\
2\end{array}$ & $\begin{array}{l}13 \\
50 \\
58 \\
69 \\
51 \\
44 \\
55 \\
34 \\
27 \\
44 \\
42 \\
26 \\
50\end{array}$ & $\begin{array}{l}18 \\
66 \\
55 \\
85 \\
51 \ddagger \\
30 \\
59 \\
35 \\
34 \\
52 \\
50 \\
33 \\
68\end{array}$ & $\begin{array}{l}\text { Identical twin normal } \\
7 \text { mth gestation } \\
\text { Twin died at } 1 \mathrm{dy} \\
32 \text { wk section for bleeding } \\
6 \text { mth gestation } \\
\text { Toxaemia of pregnancy } \\
7 \frac{1}{2} \text { mth gestation } \\
\text { No spontaneous seizures for } 18 \mathrm{mth}\end{array}$ \\
\hline $\begin{array}{l}\text { Yes } \\
\text { Yes } \\
\text { Yes } \\
\text { Yes } \\
\text { Yes }\end{array}$ & $\begin{array}{l}18 \\
20 \\
12 \\
24 \\
10\end{array}$ & $\begin{array}{c}0 \\
++ \\
++ \\
++ \\
0\end{array}$ & $\begin{array}{l}4 \\
2 \\
0 \\
0 \\
1\end{array}$ & $\begin{array}{l}19 \\
52 \\
40 \\
47 \\
33\end{array}$ & $\begin{array}{r}45 \\
101 \\
110 \\
146 \\
110\end{array}$ & $\begin{array}{l}\text { Growth hormone deficiency } \\
\text { Identical twin normal } \\
\text { No spells after } 7 / 12\end{array}$ \\
\hline $\begin{array}{l}\text { Yes } \\
\text { Yes }\end{array}$ & $\begin{array}{l}12 \\
12\end{array}$ & $\begin{array}{l}0 \\
0\end{array}$ & $\begin{array}{l}4 \\
2\end{array}$ & $\begin{array}{l}37 \\
30\end{array}$ & $\begin{array}{r}105 \\
85\end{array}$ & Associated seizure disorder \\
\hline No & 24 & $++t$ & 2 & 33 & 75 & \\
\hline
\end{tabular}

$=$ unconsciousness, seizure; $Q=$ every. OGTT $=$ oral glucose tolerance test.

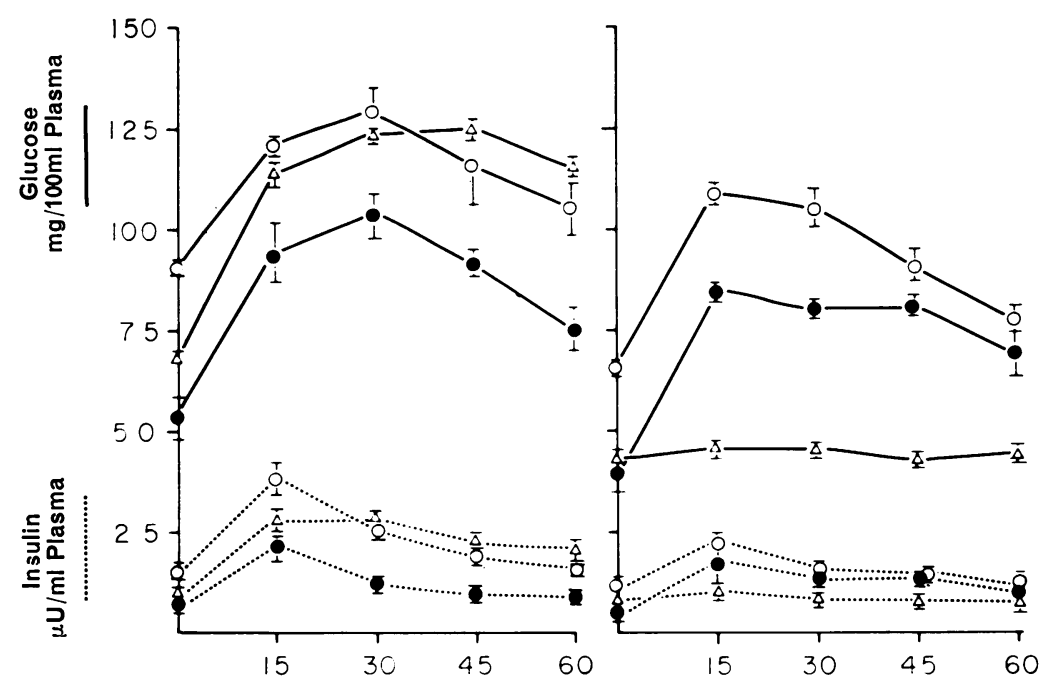

MINUTES AFTER GLUCAGON

FIG. 1.-Glucose and insulin response to glucagon in the fed (left) and fasting (right) states in normal children and hypoglycaemic patients (mean $\pm S E M$ ). $O=$ normal; $=$ glucagon responsive hypoglycaemia; $\triangle=$ glucagon unresponsive hypoglycaemia. 


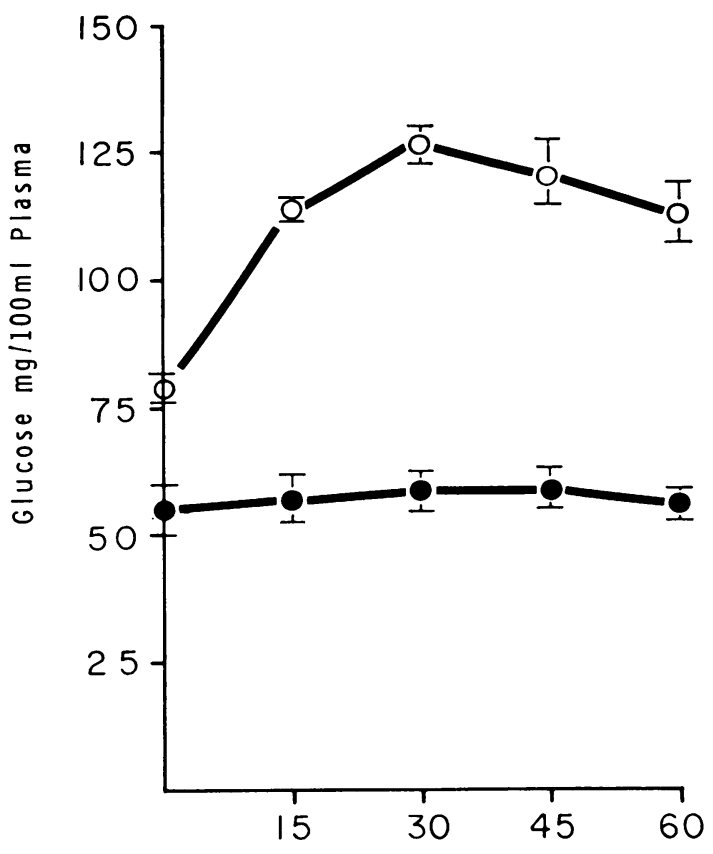

MINUTES AFTER GLUCAGON

FIG. 2.-Glucose response to glucagon after 24-hour fast during diazoxide treatment in 6 children with ketotic (idiopathic glucagon unresponsive) hypoglycaemia demonstrating restoration of glucagon responsiveness and in 3 children who did not respond (mean $\pm S E M) .0=$ responders; $=$ non-responders.

insulin in the fasting state casts further doubt on fasting hypoinsulinaemia as a mechanism.

The ketosis that some of these patients develop is not a cause of the hypoglycaemia. We have shown the development of hypoglycaemia without ketonuria, and ketone infusion has been shown to induce similar reduction in blood glucose concentration in these children as in normals (Loridan and Senior, 1970).

Gluconeogenesis during fasting is required to replenish glycogen stores (Cahill et al., 1966; Nitzan et al., 1968). Though it has been shown that gluconeogenesis from glycerol is normal when these patients are hypoglycaemic (Senior and Loridan, 1969), this source of glucose is not of great significance (Cahill et al., 1966). The more important pathway to glucose during fasting is gluconeogenesis from protein (Felig et al., 1970). The protective effect of cortisol in this condition has suggested that diminished fasting gluconeogenesis may be a factor (Colle and Ulstrom, 1964). Failure of gluconeogenesis in these children is further
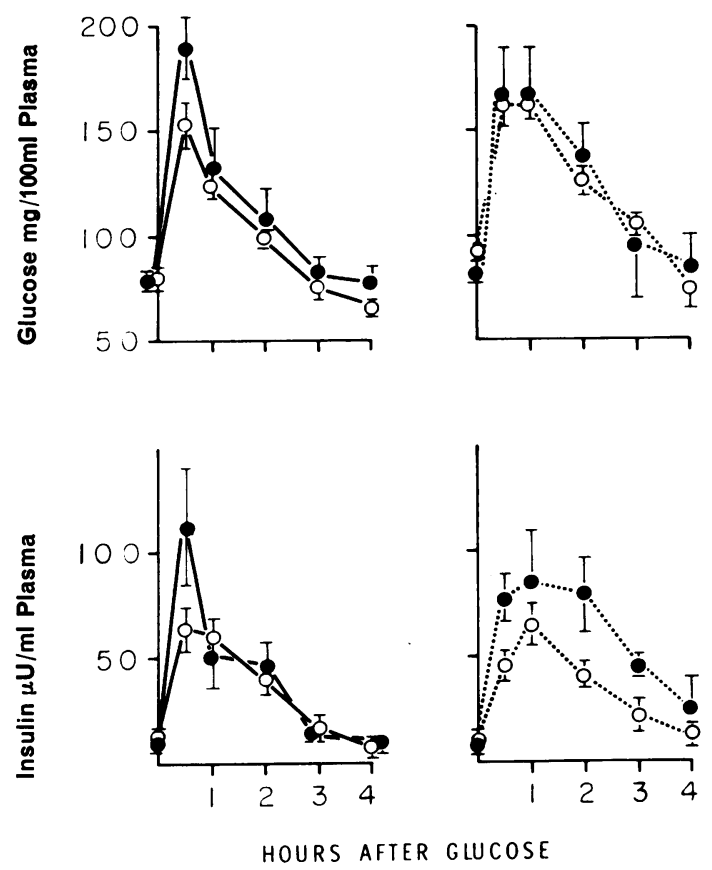

FIG. 3.-Effect of 3 days of diazoxide treatment on oral glucose tolerance in patients with ketotic (idiopathic glucagon unresponsive) hypoglycaemia (mean \pm SEM). $O=$ responders; $O=$ non responders; $-=$ untreated; $---=$ treated.

supported by the finding of absent liver glycogen after a 24-hour period of carbohydrate deprivation. After a 12-hour fast these same patients had normal concentrations of glycogen in the liver (Sauls, 1966). Recently, hypoalaninaemia has been described in children with ketotic hypoglycaemia and alanine infusion has restored their glucose levels to normal (Pagliara et al., 1971). This deficiency of the main substrate for gluconeogenesis may not be specific, however; the same phenomenon has been noted in the fasting hypoglycaemia of pregnancy (Hare, Metzger, and Freinkel, 1971). The finding of diminished epinephrine excretion during induced hypoglycaemia in this condition (Koffler, Schubert, and Hug, 1971) has led to the suggestion that children with ketotic hypoglycaemia are identical to those with adrenal medullary unresponsiveness (Broberger, Jungner, and Zetterström, 1959; Brunjes et al., 1963; Madsen, 1965). In contrast to this latter group, however, those with ketotic hypoglycaemia have sympathetic symptoms with their episodes.

Diazoxide appears to have a number of metabolic 
effects suggesting that it acts on the cyclic-AMP system in a nonspecific manner (Crawford and Bode, 1970). Hyperglycaemia after its administration is due to increased lipolysis and glycogenolysis directly and as the result of insulin suppression and the liberation of endogenous catecholamines (Loubatières et al., 1968).

The patients who failed to respond to glucagon after diazoxide therapy might represent a group whose defect lay in restoration or preservation of glycogen during fasting (Sauls, 1966). The protective effect of diazoxide related to its lipolytic effect and depression of glucose utilization would be overcome by the deleterious effects of enhanced glycogenolysis. Those who responded to glucagon while fasting and on diazoxide might have a defect in which the release of glycogen is impaired in the fasting state. In such patients, diazoxide would condition or amplify the glycogenolytic response to glucagon. It is not possible to say whether the difference between responding and nonresponding groups reflect variability of expression of the same metabolic defect or is due to different defects in gluconeogenesis.

The long-term studies indicating improvement of the ability to withstand fast and respond to glucagon in the fasting state are consistent with the clinical experience of improvement with age. That these children only begin their problems from several months to several years of age counters a simple maturation hypothesis.

Supplies of diazoxide were kindly supplied by Dr. Lawrence B. Hobson of the Schering Corporation. I wish to thank the staff of the Clinical Research Center, Mrs. Carole Oglesby, and Mrs. Charlotte Luce, who prepared the manuscript, and the physicians who referred the patients: Drs. Edzell P. Dickerson, James R. Kennedy, Charles T. Ozaki, Edward R. Westmark, Charles F. Scott, F. Edwards Rushton, John T. Simpson, James G. White, Oliver F. Deen, Elaine Ross, Charles D. Anderson, John H. Parker, and William C. Butscher.

\section{REFERENCES}

Broberger, O., Jungner, I., and Zetterström, R. (1959). Studies in spontaneous hypoglycemia in childhood. Failure to increase the epinephrine secretion in insulin-induced hypoglycemia. Fournal of Pediatrics, 55, 713.

Brunjes, S., Hodgman, J., Nowack, J., and Johns, V. J., Jr. (1963). Adrenal medullary function in idiopathic spontaneous hypoglycemia of infancy and childhood. American fournal of Medicine, 34, 168.

Cahill, G. F., Jr., Herrera, M. G., Morgan, A. P., Soeldner, J. S., Steinke, J., Levy, P. L., Reichard, G. A., Jr., and Kipnis, D. M. (1966). Hormone-fuel interrelationships during fasting. fournal of Clinical Investigation, 45, 1751.
Colle, E., and Ulstrom, R. A. (1964). Ketotic hypoglycemia. Fournal of Pediatrics, 64, 632.

Crawford, J. D., and Bode, H. H. (1970). Diabetes and the amplifier hypothesis. New England fournal of Medicine, 282, 1266.

Darrow, D. C., and Cary, M. K. (1935). A clinical and chemical study of nondiabetic ketosis with acidosis. Fournal of Pediatrics, 6, 676.

Drash, A. (1971). The hypoglycemias of childhood and their evaluation. Fournal of the Florida Medical Association, 58, 52.

Felig, P., Pozefsky, T., Marliss, E., and Cahill, G. F., Jr. (1970). Alanine: key role in gluconeogenesis. Science, 167, 1003.

Graber, A. L., Porte, D., Jr., and Williams, R. H. (1966). Clinical use of diazoxide and mechanism for its hyperglycemic effects. Diabetes, 15, 143.

Grunt, J. A., McGarry, M. E., McCollum, A. T., and Gould, J. B. (1970). Studies of children with ketotic hypoglycemia. Yale fournal of Biology and Medicine, 42, 420.

Habbick, B. F., McNeish, A. S., and Stephenson, J. B. P. (1971). Diagnosis of ketotic hypoglycaemia of childhood. Archives of Disease in Childhood, 46, 295.

Hare, J. W., Metzger, B. E., and Freinkel, N. (1971). Hypoglycemia during fasting in pregnancy: a substrate deficiency syndrome. (Abst.) Diabetes, 20 (Suppl. 1), 338.

Koffler, H., Schubert, W. K., and Hug, G. (1971). Sporadic hypoglycemia: abnormal epinephrine response to the ketogenic diet or to insulin. Fournal of Pediatrics, 78, 448.

Kogut, M. D., Blaskovics, M., and Donnell, G. N. (1969). Idiopathic hypoglycemia: a study of twenty-six children. Fournal of Pediatrics, 74, 853.

Loridan, L., and Senior, B. (1970). Effects of infusion of ketones in children with ketotic hypoglycemia. Fournal of Pediatrics, 76, 69.

Loubatières, A., Mariani, M. M., and Alric, R. (1968). The action of diazoxide on insulin secretion, medullo-adrenal secretion, and the liberation of catecholamines. Annals of the New York Academy of Sciences, 150, 226.

Madsen, A. (1965). Spontaneous hypoglycaemia with convulsions and deficient adrenaline reaction: a case occurring in one of uniovular twins. Acta Paediatrica Scandinavica, 54, 483.

Nitzan, M., and Kowadlo-Silbergeld, A. (1966). Responses to glucagon and epinephrine, and glycogen reserves in children with nondiabetic ketosis. Israel fournal of Medical Sciences, 2,683 .

Nitzan, M., Kowadlo-Silbergeld, A., Doron, M., and Laron, Z. (1968). Metabolic substrates and hormones during starvation ketosis in children. American fournal of Clinical Nutrition, 21, 1268.

Pagliara, A., Karl, I., Devivo, D., Feigin, R., and Kipnis, D. (1971). Hypoalaninemia: the cause of ketotic hypoglycemia of childhood. (Abst.) Fournal of Clinical Investigation, 50, 73a.

Sauls, H. S. (1966). Quantitation of ketosis and liver glycogen during the ketogenic test diet. 36th Annual Meeting of the Society for Pediatric Research, Atlantic City, New fersey, 29-30 April, 1966, SPR Programs and Abstracts, p. 190.

Sauls, H. S., and Ulstrom, R. A. (1967). Hypoglycemia. In Brennemann's Practice of Pediatrics, Vol. 1, Chap. 40, p. 1. Ed. by V. C. Kelley. Harper and Row, New York and Hagerstown, Maryland.

Senior, B., and Loridan, L. (1969). Gluconeogenesis and insulin in the ketotic variety of childhood hypoglycemia and in control children. Fournal of Pediatrics, 74, 529.

Van Itallie, T. B., and Bergen, S. S., Jr. (1961). Ketogenesis and hyperketonemia. American fournal of Medicine, 31, 909.

Yalow, R. S., and Berson, S. A. (1960). Immunoassay of endogenous plasma insulin in man. Fournal of Clinical Investigation, 39, 1157.

Correspondence to Dr. A. L. Rosenbloom, Department of Pediatrics, University of Florida College of Medicine, Gainesville, Florida 32601, U.S.A. 